$\mathrm{Nr}$ 6(69), 2020, s. 101-112

https://doi.org/10.12797/Politeja.17.2020.69.05

\author{
Agnieszka Małgorzata KASTORY (D) \\ Uniwersytet Jagielloński \\ agnieszka.kastory@uj.edu.pl
}

\title{
ZNACZENIE DUNAJU W EUROPEJSKIEJ SIECI DRÓG WODNYCH
}

ABSTRACT The Role of the Danube River in the Trans-European Waterway Network In the $20^{\text {th }}$ century, the Danube Region was subject to numerous and far-reaching political transformations, which had a negative impact on the expansion of the Danube waterway transport, affected mainly by political, economical and military crises that took place in the 1990s. Nowadays, only $9 \%$ of all river cargo is shipped via the Danube River. The European Union makes an effort to increase this number up to $30 \%$, and to ensure the river's permanent inclusion in the Trans-European Transport Network, with an ongoing process of adjusting the Danube shipping law to the regulations applicable to other European rivers. Nonetheless, the implementation of the EU Strategy for the Danube Region has little effect on the transportation growth in the Danube Basin so far - due to insufficient support from the European Union, the Danubian countries' unwillingness to carry out expensive investments, and difficulties related to the process of redirecting the existing trade routes.

Keywords: Danube, Rhine, Danube Commission, European Union, RhineMain-Danube Canal, EU Strategy for the Danube Region, river transport

Słowa kluczowe: Dunaj, Ren, Komisja Dunajska, Unia Europejska, Kanał RenMen-Dunaj, Strategia dla regionu Dunaju, transport rzeczny 


\section{DUNAJ I JEGO STATUS}

Dunaj jest największą (nie licząc Wołgi) rzeką Europy. Wypływa z gór Szwarcwaldu i płynie do Morza Czarnego przez $2850 \mathrm{~km}$. Jest żeglowny od Ulm do ujścia na długości $2588 \mathrm{~km}$. Obecnie przecina lub rozdziela Niemcy, Austrię, Słowację, Węgry, Chorwację, Serbię, Rumunię, Bułgarię, Mołdawię, Ukrainę. Na mocy postanowień kongresu paryskiego w 1856 r. Dunaj został umiędzynarodowiony i poddany międzynarodowej kontroli od Ulm do Suliny, ujścia środkowego ramienia delty. Potwierdzały to kolejne akty prawne, w tym konwencje dunajskie z 23 lipca 1921 r. i 18 sierpnia 1948 r.

Ze względu na położenie rzeki i dynamiczne zmiany polityczne zachodzące w basenie Dunaju w XIX i XX w. zasady jego umiędzynarodowienia zmieniały się wraz z rozwojem sytuacji politycznej. Państwa dunajskie dążyły do zachowania jak największych uprawnień na rzece, czyli prawa do pobierania opłat, dokonywania prac, stanowienia przepisów żeglugowych i sanitarnych, zachowania wyłącznego prawa do przewożenia towarów między własnymi portami (mały kabotaż) i portami naddunajskimi (duży kabotaż). Stało to w sprzeczności z dążeniami niemających dostępu do rzeki państw, które nie tylko chciały używać jej jako drogi wodnej do morza i od morza, ale także uczestniczyć przynajmniej w dużym kabotażu. Rozbieżność poglądów na temat tego, czym jest wolność żeglugi na umiędzynarodowionej rzece, sprawiła, że do wybuchu I wojny światowej na odcinku Dunaju kontrolowanym przez Austrię (potem Austro-Węgry) państwa postronne nie mogły przewozić towarów między portami dunajskimi, a jedynie transportować je od morza i do morza.

Rzeczywista wolność żeglugi rozumiana jako traktowanie wszystkich państw na zasadzie zupełnej równości była w tym czasie zagwarantowana jedynie na dolnym odcinku rzeki, od Braiły do ujścia, gdzie działała Europejska Komisja Dunaju złożona z delegatów Wielkiej Brytanii, Francji, Rosji, Austrii, Prus, Turcji i Królestwa Sardynii. To ona zdecydowała, że żegluga morska będzie się odbywała przez Sulinę. Ze względu na słabość Turcji, a następnie Rumunii, której niepodległość uznano dopiero w 1878 r., Europejska Komisja Dunaju zwiększała swe uprawnienia i samodzielnie decydowała o podejmowaniu prac rzecznych, ustalała i pobierała opłaty żeglugowe, tworzyła regulamin żeglugi, wykonywała funkcje sądownicze, dbała o równe traktowanie wszystkich statków wpływających na Dunaj, mianowała najwyższych urzędników portowych w Sulinie. Rząd niepodległej Rumunii bezskutecznie dążył do ograniczenia jej uprawnień.

Po I wojnie światowej, zakończonej klęską Niemiec i Austro-Węgier, Wielka Brytania i Francja doprowadziły na konferencji pokojowej w Paryżu do przyjęcia radykalnej zasady umiędzynarodowienia niemieckich rzek: Renu, Dunaju, Łaby, Odry i Niemna. Na mocy konwencji dunajskiej z 1921 r. wszystkie jednostki mogły wpływać na Dunaj, korzystać bez ograniczeń z prawa do dużego kabotażu, a w małym kabotażu za porozumieniem z właściwym państwem nadrzecznym. Konwencja potwierdziła uprawnienia Europejskiej Komisji Dunaju i powołała do życia Międzynarodową Komisję Dunaju, która swym zasięgiem obejmowała Dunaj od Ulm do Braiły. W obu zasiadały obok 
przedstawicieli państw nadrzecznych reprezentanci państw postronnych: Wielkiej Brytanii, Francji i Włoch. Komisje dunajskie posiadały ważne uprawnienia w dziedzinie wykonywania i kontrolowania prac na rzece, ustalania regulaminów rzecznych i wysokości opłat żeglugowych. Europejska Komisja zachowała także uprawnienia sądowe.

W okresie międzywojennym państwa naddunajskie starały się ograniczyć uprawnienia komisji rzecznych. Rumunia uczyniła to 18 sierpnia 1938 r. drogą porozumienia zawartego w Sinaia, Niemcy zaś - wypowiadając 14 listopada 1936 r. klauzule rzeczne traktatu wersalskiego, co doprowadziło do paraliżu Międzynarodowej Komisji Dunaju ${ }^{1}$.

Po II wojnie światowej ustrój żeglugi na Dunaju ponownie się zmienił za sprawą Związku Radzieckiego, który dążył do rozszerzenia uprawnień zależnych od siebie państw nadrzecznych, ograniczenia uprawnień komisji dunajskich, odsunięcia od kontroli rzeki państw nieleżących nad Dunajem. Realizację tych celów umożliwiła ZSRR przedłużająca się po zakończeniu wojny okupacja Niemiec i Austrii, które tym samym wyłączono z dyskusji nad przyszłym ustrojem żeglugi. Natomiast Czechosłowacja, Węgry, Jugosławia, Rumunia i Bułgaria przyjęły bez zastrzeżeń radziecki punkt widzenia. Nowy układ sił w basenie Dunaju ujawniła konferencja dunajska w Belgradzie, odbywająca się od 30 lipca do 18 sierpnia 1948 r. Obecne na niej Francja, Wielka Brytania i Stany Zjednoczone (jako mocarstwo okupacyjne Austrii i Niemiec) okazały się bezradne wobec większości reprezentowanej przez delegatów państw dunajskich, którymi sprawnie kierował przedstawiciel ZSRR Andrzej Wyszyński. Wyszyński, szermując w złej wierze hasłami sprawiedliwości dziejowej i suwerenności państw oraz domagając się głosowania zwykłą większością (co miało być najwyższym wyrazem demokracji), postawił państwa zachodnie na przegranej pozycji. Wszystkie poprawki zgłaszane przez ich delegatów zostały odrzucone. Projekt konwencji przywieziony z Moskwy przez Wyszyńskiego został zaakceptowany. Przebiegowi tego spektaklu, jakim w rzeczywistości była konferencja belgradzka, przyglądał się w milczeniu delegat Austrii mający status obserwatora. Delegat Niemiec nie przybył, ponieważ nie istniał jeszcze rząd niemiecki².

Konwencja przyjęta 18 sierpnia 1948 r., obowiązująca do dnia dzisiejszego, przerywała prawnomiędzynarodową ciągłość instytucji działających na Dunaju. Powstała jedna Komisja Dunajska, obejmująca swym zasięgiem odcinek Dunaju od Ulm do ujścia. W jej skład weszli delegaci wyłącznie państw dunajskich. Uprawnienia Komisji Dunajskiej zostały ograniczone na rzecz państw, które otrzymały prawo wykonywania prac rzecznych, stanowienia regulaminu żeglugi, wykonywania uprawnień sądowych na swoich odcinkach rzeki. Komisja miała dbać o przestrzeganie konwencji, dążyć do ujednolicenia regulaminów rzecznych, doradzać państwom nadrzecznym. Statki różnych bander mogły wpływać na rzekę i przewozić towary, ale mały kabotaż

Szerzej na ten temat piszę w opracowaniu Żegluga dunajska w polityce międzynarodowej $w$ XX wieku, Kraków 2011.

A. Kastory, Żegluga dunajska..., s. 194-212; przebieg konferencji: Conférence Danubienne, Beograd 1948. Recueil des documents, Аунайска конференция. Бемград 1948. Сборник документов, Веоgrad, Бемград 1949. 
był zarezerwowany dla państw nadrzecznych. Członkami Komisji Dunajskiej zostały ZSRR, Rumunia, Bułgaria, Jugosławia, Węgry, Czechosłowacja i od 1959 r. Austria. Ze względu na nieobecność Republiki Federalnej Niemiec Komisja nie kontrolowała niemieckiego odcinka rzeki ${ }^{3}$.

Przyjęte w konwencji z 1948 r. rozwiązania były anachroniczne z punktu widzenia rozwoju tendencji integracyjnych w Europie. Poza tym sposób jej przyjęcia sprawił, że delegaci Stanów Zjednoczonych, Francji i Wielkiej Brytanii nie złożyli podpisów pod konwencją, a rządy Francji i Wielkiej Brytanii nadal uznawały konwencję z 1921 r., co potęgowało prawny bałagan.

W okresie zimnej wojny żegluga dunajska stała się domeną przede wszystkim państw nadrzecznych. Powodem były nie tyle zapisy konwencji z 1948 r., która jednak gwarantowała wolność żeglugi, co zerwanie współpracy gospodarczej między Wschodem a Zachodem Europy i związana z tym zmiana szlaków komunikacyjnych.

Po upadku rządów komunistycznych i odzyskaniu przez państwa Europy Środkowej pełnej suwerenności pojawiła się szansa zwiększenia znaczenia dunajskiej drogi wodnej, tym bardziej że 25 września 1992 r. został uroczyście otwarty kanał Ren-Men-Dunaj, nazwany Kanałem Europejskim. Jego budowę rozpoczęła spółka Rhein-Main-Donau w 1921 r., jednak od 1966 r. prace w coraz większej mierze finansował rząd Republiki Federalnej Niemiec, licząc na wzrost znaczenia dróg wodnych, a tym samym zwrot kosztów budowy. Zakończenie zimnej wojny umożliwiło także przyjęcie zjednoczonych Niemiec do Komisji Dunajskiej. Stało się to poprzez podpisanie Protokotu dodatkowego do konwencji dunajskiej 26 marca $1998 \mathrm{r}$. w Budapeszcie. Na jego mocy Niemcy przystąpiły do konwencji dunajskiej z 1948 r., jednak uzyskały zgodę na wyłączenie spod jurysdykcji Komisji Dunajskiej odcinka rzeki między Ulm a Kelheim. Nie wyraziły również zgody, by umiędzynarodowić Kanał Europejski. Protokót dodatkowy zmienił zasady członkostwa w Komisji Dunajskiej. Dzięki temu mogą w niej zasiadać delegaci sygnatariuszy konwencji dunajskiej, a nie tylko państw dunajskich. Wskutek tego członkostwo w Komisji Dunajskiej mogła zachować Rosja, która obecnie nie graniczy z rzeką. Za państwa sygnatariuszy i ich sukcesorów uznano: Austrię, Słowację, Węgry, Chorwację, Rumunię, Jugosławię (obecnie Serbia), Bułgarię, Ukrainę, Mołdawię, Rosję. Obok francuskiego i rosyjskiego językiem Komisji Dunajskiej stał się niemieckí .

\section{MOŻLIWOŚCI ROZWOJU DUNAJSKIEJ DROGI WODNEJ}

Częste zmiany ustroju żeglugi dunajskiej, brak ciągłości w zarządzaniu rzeką, przemiany polityczne zachodzące w basenie Dunaju nie sprzyjały i nie sprzyjają ustabilizowaniu i harmonijnemu rozwojowi żeglugi dunajskiej. Kryzys gospodarczy, który dotknął

Konwencja dotycząca ustroju żeglugi na Dunaju, „Zbiór dokumentów” pod redakcją J. Makowskiego, 1948/1949, wrzesień 1948, Polski Instytut Spraw Międzynarodowych, nr 57, s. 635-661.

A. Kastory, Plany wykorzystania śródlądowych dróg wodnych w strategii Unii Europejskiej ożywienia regionu naddunajskiego, [w:] Nowe strategie na nowy wiek - granice i możliwości integracji regionalnych i globalnych. Praca zbiorowa, red. nauk. M. Chorośnicki i in., Kraków 2013, s. 153. 
wiele państw regionu w latach 90. XX w., prywatyzacja floty, odpływ pracowników na Zachód negatywnie odbiły się na żegludze. O ile w 1980 r. przewożono Dunajem rocznie około $90 \mathrm{mln}$ ton towarów, to w 1990 r. zaledwie kilka milionów. W 1999 r. w trakcie działań Paktu Północnoatlantyckiego przeciw Nowej Jugosławii (24 marca 9 czerwca 1999 r.) jej rząd zamknął dla żeglugi swój odcinek Dunaju. Bombardowania prowadzone przez lotnictwo NATO spowodowały zwalenie do rzeki mostu w Nowym Sadzie i zablokowanie żeglugi ${ }^{5}$. Na rzece zbudowano most pontonowy, udrożnienie kanału żeglugowego pochłonęło $26 \mathrm{mln}$ euro, z czego 85\% wyasygnowała Unia Europejska, a $15 \%$ państwa członkowskie Komisji Dunajskiej. Sam most stanął ponownie w 2005 r. $^{6}$

Ponadto występujące przez kilka lat, począwszy od 2003 r., niskie stany wód Dunaju uniemożliwiały żeglugę przy pełnym ładunku. Przedsiębiorstwa żeglugowe straciły część frachtu, a towary trafily do transportu kołowego i kolejowego. Do wyboru drogi wodnej zniechęcały również kolejki do śluz i brak infrastruktury do przewożenia ładunków kontenerowych ${ }^{7}$. Problem stanu wody pozostawał stałą troską Komisji Dunajskiej w kolejnych latach. W pierwszej połowie 2020 r. (od lutego do lipca) na całym odcinku rzeki utrzymywał się niższy od średniej poziom wody.

Warunkiem rozwoju żeglugi dunajskiej jest modernizacja infrastruktury i floty rzecznej. Wprawdzie w rejon Dunaju napływa kapitał zachodni i pojawiają się nowe jednostki pływające, ale pracownicy wolą pracować w żegludze reńskiej'. Uzyskanie połączenia z Renem poprzez Kanał Europejski nie przyczyniło się do zwiększenia dynamiki rozwoju żeglugi dunajskiej. Kanał jest wykorzystywany poniżej swych możliwości: rocznie można nim przewieźć $15 \mathrm{mln}$ ton towarów, natomiast obecnie przepływa nim około $10 \mathrm{mln}$ ton, z czego tylko około połowa wpływa z Dunaju. Nie jest to wiele, zważywszy na to, że rocznie europejskimi rzekami przewozi się około $400 \mathrm{mln}$ ton towarów. Dunajskie statki wpływające na Ren stanowią $2 \%$ floty reńskiej, statki reńskie zaś wpływające na Dunaj stanowią 15\% floty dunajskiej. Na Renie nadal dominującym kierunkiem transportu jest kierunek z południa ku północy do portów ARA (Amsterdam, Rotterdam, Antwerpia) ${ }^{10}$.

\section{Tamże, s. 159.}

6 L'axefluvial Rhin-Danube: mythes et realites, niesygnowany tekst na stronie Centralnej Komisji Żeglugi na Renie, s. 4, [online] https://ccr-zkr.org/files/histoireCCNR/13_axe-fluvial-rhin-danube.pdf, 24 II 2021.

E. Keskeny, Marché dans la région du Danube, [w:] Renforcer le transport par voies navigables. Aller de l'avant grâce à la coopération paneuropéenne, Paris 2006, s. 25-26, [online] https://www.itf-oecd. $\mathrm{org} /$ sites/default/files/docs/06watpaneuropf_0.pdf, 16 IX 2020.

8 Information du Secretariat sur le thème „Observation du marché de la navigation danubienne: premier semestre de 2020", Commision du Danube, 7-9 X 2020, s. 9, [online] https://www.danubecommission.org/dc/fr/navigation-danubienne/observation-du-marche-de-la-navigation-danubienne/observation-du-marche-de-la-navigation-danubienne-premier-semestre-de-2020/, 14 X 2020.

9 L'axe fluvial..., s. 7

10 Tamże, s. 6-7; J.M. Woehrling, La coopération internationale dans le domaine de la navigation fluviale européenne: les instances de coopération pour la navigation rhénane et danubienne, [online] https:// www.ccr-zkr.org/files/histoireCCNR/14_cooperation-rhin-danube.pdf, 13, 24 II 2021. 
Tabela 1. Całkowita ilość towarów przewożonych Dunajem w latach 2011-2015 w tys. ton ${ }^{11}$

\begin{tabular}{|c|c|c|c|c|c|}
\hline & $\begin{array}{c}\text { Całkowita } \\
\text { ilość prze- } \\
\text { wożonych } \\
\text { towarów }\end{array}$ & $\begin{array}{c}\text { Towary } \\
\text { wwiezione } \\
\text { przez kanal } \\
\text { Suliny }\end{array}$ & $\begin{array}{c}\text { Towary } \\
\text { wwiezione } \\
\text { przez ramię } \\
\text { Kilia }\end{array}$ & $\begin{array}{c}\text { Towary } \\
\text { wwiezione } \\
\text { przez kanał } \\
\text { Dunaj- } \\
\text { Morze } \\
\text { Czarne }\end{array}$ & $\begin{array}{c}\text { Towary } \\
\text { wwiezione } \\
\text { przez kanał } \\
\text { Men-Dunaj }\end{array}$ \\
\hline 2011 & 36111 & 582 & 1137 & 11615 & 2229 \\
\hline 2012 & 33959 & 328 & 792 & 13721 & 2365 \\
\hline 2013 & 38361 & 459 & 732 & 13966 & 2727 \\
\hline 2014 & 45791 & 459 & 185 & 13966 & 2420 \\
\hline 2016 & 56960 & 585 & 18 & 14018 & 2045 \\
\hline 2017 & 32554 & 513 & 26 & 14554 & 1930 \\
\hline
\end{tabular}

Czynnikiem utrudniającym integrację żeglugi na Renie i Dunaju są odmienne regulacje prawne stosowane na obu rzekach, różne uprawnienia Komisji Dunajskiej i Centralnej Komisji Żeglugi na Renie oraz niedostateczny stan infrastruktury żeglugowej na Dunaju. Centralna Komisja Żeglugi na Renie może tworzyć jednolite zasady prawne na całej rzece, a dunajska ma tylko uprawnienia do rekomendowania państwom pewnych rozwiązań. Pod koniec lat 80 . obie komisje nawiązały kontakt poprzez wymianę listów. W $2001 \mathrm{r}$. ich przedstawiciele spotkali się osobiście przy okazji podpisania $B u$ dapesztańskiej konwencji w sprawie umowy przewozu tadunków w żegludze śródląowej (CMNI). Poza tym tzw. Deklaracja z Rotterdamu przyjęta 6 września 2001 r. zachęcała obie komisje do współpracy i rozwijania żeglugi rzecznej oraz dbałości o jej bezpieczeństwo. Od tego momentu rozwija się współpraca między obiema komisjami. Rośnie liczba państw dunajskich mających status obserwatora w Centralnej Komisji Żeglugi na Renie: Austria, Bułgaria, Węgry, Słowacja, Rumunia, Ukraina, Serbia. Status obserwatora w Komisji Dunajskiej mają zaś Belgia i Francja. Powstała grupa robocza z udziałem przedstawicieli obu komisji, mająca na celu harmonizację regulaminów rzecznych. Obie komisje wzajemnie uznają swoje dokumenty dopuszczenia do żeglugi, chociaż nie jest to jeszcze generalna zasada ${ }^{12}$. Niemniej harmonizacja przepisów może się dokonywać poprzez stosowanie prawa Unii Europejskiej.

11 Według danych Komisji Dunajskiej: https://www.danubecommission.org, 7 XI 2017, oraz bieżących statystyk: Statistiques de la navigation danubienne en 2013-2014, Commission du Danube, 12-15 IV 2016, tabela nr 6, [online] http://www.danubecommission.org/uploads/doc/STATISTIC/Stat\%20 2013-2014\%20FR.pdf, 14 X 2020; Statistiques de la navigation danubienne en 2014-2015, Commission du Danube, XI 2016, tabela nr 6, [online] http://www.danubecommission.org/uploads/doc/ STATISTIC/fr_stat_2014_15.pdf, 14 X 2020; Statistiques de la navigation danubienne en 20162017, Commission du Danube, XI 2018, tabela nr 6, [online] http://www.danubecommission.org/ uploads/doc/STATISTIC/fr_stat_2016_2017.pdf, 14 X 2020.

12 L'axe fluvial..., s. 11. 
Z inicjatywy Centralnej Komisji Żeglugi na Renie, Komisji Dunajskiej i Rady Gospodarczej ONZ dla Europy w dniach 22-23 września 2005 r. odbyła się konferencja ministrów transportu, poświęcona realizacji Deklaracji z Rotterdamu ${ }^{13}$.

Obok harmonizacji przepisów poważnym problemem pozostaje rozwój infrastruktury żeglugowej na Dunaju i jego żeglownych dopływach. Problem ten był już wielokrotnie podnoszony na spotkaniach ministrów transportu i szefów delegacji państw naddunajskich odbywających się w 2012 r. w Luksemburgu, w 2014 w Brukseli, w 2016 w Rotterdamie i w 2018 w Brukseli. W trakcie spotkania w 2018 r. delegaci państw dunajskich przyznali, że nie uzyskali znaczącego polepszenia stanu żeglugi na Dunaju porównaniu ze stanem z $2014 \mathrm{r}^{14}$

\section{ŻEGLUGA DUNAJSKA W PERSPEKTYWIE POLITYKI TRANSPORTOWEJ UNII EUROPEJSKIEJ}

Komisja Europejska traktuje transport rzeczny jako jeden z trzech głównych rodzajów transportu obok drogowego i kolejowego. Argumentuje, że połowa ludności Europy mieszka w pobliżu dróg żeglownych, tam też są skoncentrowane największe centra przemysłowe. Najważniejszy jest oczywiście basen Renu ze względu na poziom rozwoju gospodarczego oraz infrastruktury żeglugowej, a także liczbę ludności. Około $80 \%$ towarów przewożonych rzekami w Europie płynie Renem ${ }^{15}$.

Basen Dunaju jest uznawany za drugi pod względem znaczenia. Może stanowić połączenie między morzami Północnym a Czarnym. Jednak Dunajem i Kanałem Europejskim przewozi się jedynie około 9\% towarów transportowanych rzekami ${ }^{16}$.

Komisja Europejska wychodzi z założenia, że transport rzeczny jest najtańszy, biorąc pod uwagę koszty paliwa, zanieczyszczeń, skutki hałasu i wypadki. Pod tym względem najdroższy jest transport kołowy - 2,01 centyma za tonę towaru przewożoną przez kilometr. W przypadku transportu kolejowego jest to 0,8 centyma, a rzecznego $0,27^{17}$. Do tego transport rzeczny jest ekonomiczny: statek może przewieźć tonę towaru prawie cztery razy dalej niż ciężarówka, konsumując tę samą ilość energii.

13 Materiały z konferencji zostały wydane w zbiorze: Renforcer le transport par voies navigables. Aller de l'avant grace à la coopération paneuropéenne, Paris 2006, [online] https://www.itf-oecd.org/sites/ default/files/docs/06watpaneuropf_0.pdf, 16 IX 2020.

14 Conclusions on effective waterway infrastructure rehabilitation and maintenance on the Danube and its navigable tributaries, Danube Ministers Meeting, Brussels 3 XII 2018, [online] https://www.danubecommission.org/dc/en/danube-commission/conclusions-of-the-danube-minister-meeting-3-december-2018-brussels/, 21 IX 2020.

15 Raport special. Le transport fluvial en Europe: aucune amélioration significative de la part modale et des conditions de navigabilité depuis 2001, Court des Comptes Européenne, Luxembourg 2015, s. 9, [online] https://www.eca.europa.eu/Lists/ECADocuments/SR15_01/SR15_01_FR.pdf, 6 XI 2017.

16 Tamże, s. 9.

17 Tamże, s. 11. 
Tabela 2. Możliwość przewiezienia tony towaru przy takim samym zużyciu energii przez różne środki transportu

\begin{tabular}{|c|c|c|c|}
\hline Środek transportu & Ciężarówka & Pociąg & Statek rzeczny \\
\hline Kilometry & 100 & 300 & 370 \\
\hline
\end{tabular}

Transport rzeczny jest jednak wolniejszy i może służyć do przewożenia towarów, które nie wymagają natychmiastowego dostarczenia na miejsce, a jego koszty spadają przede wszystkim na długich dystansach ${ }^{18}$.

Tabela 3. Koszty transportu Renem w porównaniu z kosztami transportu drogowego i kolejowego w centymach za tonę na kilometr ${ }^{19}$

\begin{tabular}{|c|c|c|}
\hline Rodzaj transportu & Dystans $200 \mathrm{~km}$ & Dystans $1000 \mathrm{~km}$ \\
\hline Drogowy & 14,30 & 8,80 \\
\hline Kolejowy & 16,04 & 7,40 \\
\hline Rzeczny & 2,73 & 1,95 \\
\hline
\end{tabular}

Popieranie żeglugi rzecznej stanowi dla Komisji Europejskiej narzędzie poszukiwania alternatywy dla mało przyjaznego środowisku transportu drogowego i dywersyfikacji transportu. Cel ten został zdefiniowany w białej księdze z $2001 \mathrm{r}$. W kolejnej białej księdze, dotyczącej transportu, z 2011 r. przewidywano skierowanie na rzeki około $30 \%$ transportu na średnim dystansie ${ }^{20}$.

Komisja Europejska uznała za główne przyczyny słabości żeglugi rzecznej występowanie na rzekach przeszkód, takich jak nisko osadzone mosty, wąskie kanały żeglugowe, śluzy, których przejście zajmuje zbyt dużo czasu. Kolejny podany powód to brak połączeń między istniejącymi drogami wodnymi ${ }^{21}$.

W 2006 r. został wdrożony w życie program NAIADES (Navigation intérieure: actions et développement en Europe) mający wspierać rozwój żeglugi śródlądowej poprzez rozbudowę i modernizację infrastruktury, uzupełnienie brakujących połączeń, likwidację wąskich gardeł i przeszkód, rozbudowę portów, kształcenie pracowników, stworzenie z transportu rzecznego elementu systemu zrównoważonego transportu ${ }^{22}$.

8 grudnia 2010 r. Komisja Europejska zakończyła pracę nad strategią dla Dunaju. Jej celem było zwiększenie transportu towarów o $20 \%$ do 2020 r. w porównaniu do roku 2010. Przewidywano w niej unowocześnienie infrastruktury, budowę połączeń z drogami lądowymi, poszukiwanie wykształconych i młodszych pracowników (Komisja wskazała, że większość pracowników przekroczyła 50. rok życia), polepszenie

\footnotetext{
18 Tamże, s. 12.

19 Tamże.

20 Tamże, s. 28.

21 Tamże, s. 6.

22 Tamże, s. 13.
} 
infrastruktury żeglugowej i zwiększenie przepustowości rzeki. W długotrwałej perspektywie planowano przystosowanie Dunaju dla jednostek o zanurzeniu 2,5 m oraz rozwój infrastruktury na jego dopływach. Komisja dostrzegła konieczność dalszego oczyszczania rzeki z wraków i innych śmieci pozostawionych po akcji NATO w $1999 \mathrm{r}$. W tym celu powstał Projekt zarządzania odpadami w żegludze śródlądowej na Dunaju (WANDA, Waste Management for Inland Navigation on the Danube Project). Komisja zaleciła lepszą współpracę między narodowymi instytucjami odpowiedzialnymi za zarząd wodami i ochroną środowiska (NEWADA, Network of Danube Waterway Administration Project, Projekt zarządu dunajskiej drogi wodnej). Wreszcie w celu uzupełnienia brakujących kadr Komisja powołała program NELI (Cooperation network for logistics and nautical education focusing on Inland Waterway Transport in the Danube corridor supported by innovative solutions, Sieć współpracy logistycznej i żeglugowej dotycząca transportu śródlądowego w korytarzu dunajskim wspierana innowacyjnymi rozwiązaniami) będący częścią programu edukacyjnego EDINNA (Education in Inland Navigation, Edukacja w Żegludze Śródlądowej). Zadania te miały być realizowane bez skierowania do strategii dodatkowych funduszy ${ }^{23}$.

\section{OCENA DZIAŁAŃ KOMISJI EUROPEJSKIEJ}

W 2015 r. ukazał się raport Europejskiego Trybunału Obrachunkowego podsumowujący audyt przeprowadzony pod kątem zwiększenia udziału żeglugi rzecznej w zrównoważonym transporcie i skutków realizacji projektów mających na celu rozwój żeglugi rzecznej, a finansowanych lub współfinansowanych przez UE. W raporcie wykazano, że od $2001 \mathrm{r}$., gdy Komisja postawiła sobie za cel przeniesienie części transportu na drogi rzeczne, nie dokonała się w tym zakresie żadna znacząca poprawa. W latach 2001-2012 udział transportu wodnego zwiększył się z 5,2\% w 2001 do 6,8\% w 2012²4. Zwiększenie udziału dróg wodnych w transporcie zaobserwowano jedynie w Belgii, Francji i Holandii ${ }^{25}$.

W latach 2006-2012 na 47 wskazanych przeszkód w żegludze zlikwidowano zaledwie pięć. Powodem był brak zainteresowania ze strony państw tym rodzajem transportu ${ }^{26}$. Trybunał Obrachunkowy stwierdził także, że 60\% realizowanych projektów transportowych ma poważne opóźnienia. Tymczasem ponad 1/3 dróg żeglownych basenu Renu i Dunaju nie spełnia norm ustalonych przez Europejską Konferencję Ministrów Transportu ${ }^{27}$.

23 A. Kastory, Plany wykorzystania..., s. 157-158; Commision Staff Working Document. Action Plan. Accompanying document to the Communication from the Commission to the European Parliament, the Council, the European Economic and Social Committee and the Committee of Regions. European Union Strategy for the Danube Region, European Commission, wersja ostateczna z 8 XII 2010 r., https://eurlex.europa.eu/legal-content/EN/TXT/PDF/?uri=CELEX:52010SC1489\&from=EN, 25 II 2021; Raport special. Le transport fluvial..., s. 28.

24 Raport special. Le transport fluvial..., s. 8-9.

25 Tamże, s. 25.

26 Tamże.

27 Tamże, s. 9. 
Trybunał podał konkretne przykłady dotyczące Dunaju. W sprawie odcinka na rzece między Straubing a Vilshofen Komisja Europejska i rząd Niemiec przedstawily dwa warianty prac: jeden bardziej oszczędzający środowisko, ale gorszy z punktu widzenia długofalowego rozwoju żeglugi, oraz drugi - mniej oszczędzający środowisko, ale korzystny dla żeglugi w długim okresie. Drugi wariant został opracowany niezwykle szczegółowo i kosztował $30 \mathrm{mln}$ euro, z czego połowę zapłaciła UE. Projekt korzystniejszy dla żeglugi został początkowo zaopiniowany pozytywnie, po czym nieoczekiwanie niemieckie władze zdecydowały się wybrać wersję bardziej korzystną dla środowiska ${ }^{28}$. Nie udało się także sfinalizować projektu za $8 \mathrm{mln}$ euro, w połowie finansowanego przez UE, który przewidywał poprawę warunków żeglugi na węgierskim odcinku Dunaju. Projekt utknął bowiem w węgierskich sądach po zaskarżeniu decyzji środowiskowej ${ }^{29}$.

W podsumowaniu Trybunał Obrachunkowy wskazał, że przewidywane od $2001 \mathrm{r}$. strategie rozwoju transportu rzecznego nie zostały zrealizowane, a polepszenie stanu dróg wodnych jest niedostateczne. Projekty współfinansowane przez UE nie doprowadziły do polepszenia żeglugi i zwiększenia ilości towarów przewożonych rzekami. Rozwój transportu rzecznego wymaga silnej współpracy państw członkowskich. Przy realizacji dużych projektów należy uwzględnić aspekty polityczne i środowiskowe. Tymczasem państwa członkowskie zaproponowały niewiele projektów, na dodatek mało użytecznych z punktu widzenia polepszenia żeglugi. Jeśli chodzi o Dunaj, to w okresie między 2001 a 2012 r. niewielki wzrost ilości przewożonych towarów odnotowała Austria, Węgry i Rumunia. Słowacja odnotowała spadek (o połowę) podobnie jak Bułgaria, Czechy nie zanotowały zmian ${ }^{30}$.

Trybunał Obrachunkowy wskazał ponadto, że projektom finansowanym przez UE brakuje spoistości i tylko kilka z nich pozwoliło poprawić żeglowność. Był to efekt powierzchownej analizy, niejasno określonych celów, braku badań dotyczących tego, na ile likwidacja przeszkód w danym miejscu spowoduje skierowanie transportu na rzekę, przeznaczenia na te działania niewielkich środków, braku koordynacji działań podejmowanych na poziomie państw. Audytorzy zarzucili także Komisji Europejskiej brak oszacowania kosztów inwestycji rzecznych ${ }^{31}$.

Trybunał Obrachunkowy zalecił, by skłonić państwa członkowskie do priorytetowego traktowania projektów związanych z korytarzami komunikacyjnymi i skoncentrowania się na tych drogach wodnych, których polepszenie od razu przełoży się na stan transportu wodnego. Według Trybunału Obrachunkowego Komisja Europejska powinna w przyszłości dokonywać pogłębionej analizy rynku oraz korzyści wynikających z żeglugi śródlądowej, lepiej koordynować działania państw zmierzające do budowy Transeuropejskiej Sieci Transportowej, tak by wyznaczać cele wykonalne i określać realne etapy likwidowania wąskich gardeł komunikacyjnych w połączeniach europejskich ${ }^{32}$.

\footnotetext{
Tamże, s. 25.

Tamíe.

Tamże, s. 39.

Tamże, s. 27.

Tami̇e, s. 7-8.
} 


\section{ZAKOŃCZENIE}

Dunaj jako droga wodna ma bardzo duży potencjał. Można go zwiększać, włączając w system żeglugi dunajskiej kolejne spławne rzeki. Jednak powolny wzrost przewozów towarowych na Dunaju pozwala sformułować wniosek, że wprawdzie żegluga śródlądowa jest najtańsza, ale tylko tam, gdzie nie jest przerywana zbyt często z powodów politycznych i gdzie połączenia wodne już istnieją, a szlaki handlowe się ustabilizowały. Koszty stworzenia nowej drogi wodnej, a nawet modernizacji już istniejącej zniechęcają państwa do podejmowania tego trudu, tym bardziej że istnieje poważne ryzyko co do zwrotu kosztów inwestycji w rozsądnej perspektywie. Unia Europejska, zachęcając do dywersyfikacji środków transportu, nie dokonała rzetelnej analizy opłacalności modernizacji i budowy nowych dróg wodnych. Poza tym użeglownienie rzek budzi coraz większy społeczny opór ze względu na ochronę ekosystemu i lęk przed niedoborem wody. Uwzględnienie ochrony środowiska przy pracach rzecznych bardzo podnosi koszty inwestycji. Nie znaczy to, że Dunaj nie może już odegrać ważnej roli, a połączenie Morza Północnego i Czarnego pozostanie europejskim marzeniem. Warunkiem jednak jest długotrwały okres pokoju w regionie, rozszerzenie Unii Europejskiej o kolejne państwa naddunajskie oraz umocnienie integracji kontynentu. Inwestowanie w kosztowne drogi wodne ma sens tylko wtedy, jeśli będą one stanowiły część europejskiej sieci komunikacyjnej. Droga wodna nie może prowadzić donikąd.

\section{BIBLIOGRAFIA}

\section{Dokumenty publikowane}

Commission Staff Working Document. Action Plan. Accompanying document to the Communication from the Commission to the European Parliament, the Council, the European Economic and Social Committee and the Committee of Regions. European Union Strategy for the Danube Region, European Commission, wersja ostateczna z 8 XII 2010 r., [online] https://eur-lex. europa.eu/legal-content/EN/TXT/PDF/?uri=CELEX:52010SC1489\&from=EN.

Conclusions on effective waterway infrastructure rehabilitation and maintenance on the Danube and its navigable tributaries, Danube Ministers Meeting, Brussels 3 XII 2018, [online] https:// www.danubecommission.org/dc/en/danube-commission/conclusions-of-the-danubeminister-meeting-3-december-2018-brussels/.

Conférence Danubienne, Beograd 1948. Recueil des documents, Аунайска конференция. Бемград 1948. Сборник документов [Dunajska konferenciâ. Belgrad 1948. Sbornik dokumentov], Beograd, БемграА, 1949.

Information du Secretariat sur le thème "Observation du marché de la navigation danubienne: premier semestre de 2020", Commission du Danube, 7-9 X 2020, [online] https://www. danubecommission.org/dc/fr/navigation-danubienne/observation-du-marche-de-lanavigation-danubienne/observation-du-marche-de-la-navigation-danubienne-premiersemestre-de-2020/. 
Konwencja dotycząca ustroju żeglugi na Dunaju, „Zbiór dokumentów” pod redakcją J. Makowskiego, 1948/1949, wrzesień 1948, Polski Instytut Spraw Międzynarodowych, nr 57.

Raport special. Le transport fluvial en Europe: aucune amélioration significative de la part modale et des conditions de navigabilité depuis 2001, Court des Comptes Europeenne, Luxembourg 2015, [online] https://www.eca.europa.eu/Lists/ECADocuments/SR15_01/ SR15_01_FR.pdf.

Statistiques de la navigation danubienne en 2013-2014, Commission du Danube, 12-15 IV 2016, [online] http://www.danubecommission.org/uploads/doc/STATISTIC/Stat $\% 20$ 2013-2014\%20FR.pdf.

Statistiques de la navigation danubienne en 2014-2015, Commission du Danube, XI 2016, [online] http://www.danubecommission.org/uploads/doc/STATISTIC/fr_stat_2014_15.pdf. Statistiques de la navigation danubienne en 2016-2017, Commission du Danube, XI 2018, [online] http://www.danubecommission.org/uploads/doc/STATISTIC/fr_stat_2016_2017.pdf

\section{Artykuły i opracowania}

L'axe fluvial Rhin-Danube: mythes et realites, niesygnowany tekst na stronie Centralnej Komisji Żeglugi na Renie, [online] https://ccr-zkr.org/files/histoireCCNR/13_axe-fluvial-rhin-danube.pdf.

Kastory A., Plany wykorzystania śródlądowych dróg wodnych w strategii Unii Europejskiej ożywienia regionu naddunajskiego, [w:] Nowe strategie na nowy wiek - granice i możliwości integracji regionalnych i globalnych, red. nauk. M. Chorośnicki i in., Kraków 2013.

Kastory A., Żegluga dunajska w polityce międzynarodowej w XX wieku, Kraków 2011.

Keskeny E, Marché dans la région du Danube, [w:] Renforcer le transport par voies navigables. Aller de l'avant grâce à la coopération paneuropéenne, Paris 2006, [online] https://www.itf-oecd.org/sites/default/files/docs/06watpaneuropf_0.pdf.

Renforcer le transport par voies navigables. Aller de l'avant grâce à la coopération paneuropéenne, Paris 2006, [online] https://www.itf-oecd.org/sites/default/files/docs/06watpaneuropf_0.pdf. Woehrling J.M., La coopération internationale dans le domaine de la navigation fluviale européenne: les instances de coopération pour la navigation rhénane et danubienne, [online] https:// www.ccr-zkr.org/files/histoireCCNR/14_cooperation-rhin-danube.pdf.

\section{Strony internetowe}

Strona Komisji Dunajskiej, [online] https://www.danubecommission.org.

Agnieszka Małgorzata KASTORY - dr hab., aktualnie jest zatrudniona na stanowisku prof. nadzw. UJ w Katedrze Stosunków Międzynarodowych i Polityki Zagranicznej Instytutu Nauk Politycznych i Stosunków Międzynarodowych. Do jej najważniejszych publikacji należą: Rozbiór Rumunii w 1940 roku (2002); Żegluga dunajska w polityce międzynarodowej w XX wieku (2011); Rola Obywatelskiego Klubu Parlamentarnego w ksztattowaniu polskiej polityki wschodniej w latach 1989-1991 (2018). 